\title{
Lorneic acids $C$ and $D$, new trialkyl-substituted aromatic acids isolated from a terrestrial Streptomyces sp.
}

\author{
Ritesh Raju ${ }^{1,2}$, Oleksandr Gromyko ${ }^{3}$, Viktor Fedorenko ${ }^{3}$, Andriy Luzhetskyy ${ }^{1,2}$ and Rolf Müller ${ }^{1,2}$ \\ The Journal of Antibiotics (2013) 66, 347-349; doi:10.1038/ja.2013.18; published online 3 April 2013
}

Keywords: actinomycetes; aromatic acids; lorneic acids; natural products chemistry

Our ongoing research into the chemical diversity of terrestrial actinomycetes associated with the plant rhizosphere has led to the discovery of rare metabolites, such as leopolic acid $\mathrm{A}^{1}$ and juniperolide $\mathrm{A},{ }^{2}$ which were isolated from Streptomyces sp. cultured from the rhizosphere of the plant Juniperus excelsa. The discovery of such rare and chemically diverse structures further prompted us to investigate this new source of biodiversity in order to expand and enhance our chances of discovering novel secondary metabolites. During our recent investigation into the secondary metabolism of rare terrestrial actinomycetes, we recovered a Streptomyces sp. (Lv-4-15) from the root zone of the plant Phyllostachys viridi-glaucescens. HPLC-DAD-MS analysis of a small-scale liquid cultivation $(100 \mathrm{ml})$ revealed biosynthetically related compounds $(\mathrm{m} / z 260(\mathbf{1})$ and 232 (2)) sharing a common UV spectrum ( $\lambda_{\max }=210$ and $\left.254 \mathrm{~nm}\right)$.

The Streptomyces sp. (Lv-4-15) was cultivated in M medium (61) for 8 days at $30^{\circ} \mathrm{C}$ and then extracted with ethyl acetate (5l) to give a crude extract of $112.6 \mathrm{mg}$. The crude extract was fractionated by sequential trituration with $20 \mathrm{ml}$ each of hexane, $\mathrm{CH}_{2} \mathrm{Cl}_{2}$ and $\mathrm{MeOH}$ to afford 39.6, 40.7 and $11.6 \mathrm{mg}$ fractions, respectively. The $\mathrm{CH}_{2} \mathrm{Cl}_{2}$ fraction was subsequently purified by semi-preparative reverse phase HPLC to yield compounds $1\left(t_{\mathrm{R}}=26.5 \mathrm{~min}, 0.9 \mathrm{mg}\right)$ and $2\left(t_{\mathrm{R}}=24.6\right.$ min, $0.6 \mathrm{mg}$ ). An account of the spectroscopic analysis leading to the assignment of structures to lorneic acids C (1) and D (2) is presented below.

$\operatorname{HRESI}(+)$ MS analysis of lorneic acid C (1) (Table 1, Supplementary Figure S3) revealed a pseudomolecular ion $\left([\mathrm{M}+\mathrm{Na}]^{+}\right)$ indicative of a molecular formula $\left(\mathrm{C}_{17} \mathrm{H}_{24} \mathrm{O}_{2} \mathrm{Na}\right)$ requiring six double bond equivalents. The NMR (methanol- $d_{4}$ ) (Table 2) data (Supplementary Figures S1a-d) revealed a 1,2,4-trisubstituted benzene ring as well as a (E)-1,2-disubstituted double bond. Analysis of the 2D NMR COSY data (Table 2) (Figure 1) identified three isolated spin systems. These included (i) a 1-substituted (E)-but-1-ene (C-13 to C-16); (ii) a 3,4-disubstituted toluene (C-7 to C-12, including C-17) and (iii) a 1,5-disubstituted pentane (C-2 to C-6). HMBC correlations from $\mathrm{H}-11\left(\delta_{\mathrm{H}} 7.21\right)$ to $\mathrm{C}-13\left(\delta_{\mathrm{C}} 127.8\right)$ and $\mathrm{H}_{2}-6\left(\delta_{\mathrm{H}} 2.62\right)$ to $\mathrm{C}-8$ $\left(\delta_{\mathrm{C}}\right.$ 128.4) established the point of attachment of the but-1-ene and the pentane side chains onto the 3,4-disubstituted toluene. The carboxylic acid functionality was positioned on the methylene $\mathrm{H}_{2}-2\left(\delta_{\mathrm{H}} 2.26\right)$ of the 1,5-di-substituted pentane side chain based on $\mathrm{HMBC}$ correlations from both $\mathrm{H}_{2}-2$ and $\mathrm{H}_{2}-3\left(\delta_{\mathrm{H}} 1.62\right)$ to $\mathrm{C}-1$ $\left(\delta_{\mathrm{C}} 178.1\right)$.

HRESI $(+) M S$ analysis of lorneic acid D (2) (Table 1, Supplementary Figure S4) revealed a pseudomolecular ion ([M+ $\mathrm{Na}]^{+}$) indicative of a molecular formula $\left(\mathrm{C}_{15} \mathrm{H}_{20} \mathrm{O}_{2} \mathrm{Na}\right)$. A high degree of similarity between the ${ }^{1} \mathrm{H}$ NMR spectrum of $\mathbf{2}$ and $\mathbf{1}$ followed by a close examination of the NMR data (Supplementary Figures S2a-d) revealed that the 3,4-disubstituted toluene and the but1-ene substituents remained unchanged, with the only change observed for the side chain now identified as butyric acid (C-1-C-4). The trialkyl-substituted aromatic acids belong to the rare class of

Table 1 Physico-chemical properties of 1 and 2

\begin{tabular}{lcc}
\hline & 1 & 2 \\
\hline Appearance & White solid & White solid \\
& & \\
HR-ESI-MS (m/z) & & \\
Found & $283.1668[\mathrm{M}+\mathrm{Na}]^{+}$ & $255.1352[\mathrm{M}+\mathrm{Na}]^{+}$ \\
Calcd & 283.1674 & 255.1360 \\
& $\left(\mathrm{C}_{17} \mathrm{H}_{24} \mathrm{O}_{2} \mathrm{Na}\right)$ & $\left(\mathrm{C}_{15} \mathrm{H}_{20} \mathrm{O}_{2} \mathrm{Na}\right)$ \\
UV $\lambda_{\max } \mathrm{nm}(\log \varepsilon)(\mathrm{MeOH})$ & $210(4.10), 254(3.82)$ & $210(4.10), 254(3.82)$ \\
& &
\end{tabular}

${ }^{1}$ Department of Microbial Natural Products, Helmholtz Institute for Pharmaceutical Research Saarland (HIPS), Helmholtz Centre for Infection Research (HZI), Saarland University, Saarbrücken, Germany; ${ }^{2}$ Department of Pharmaceutical Biotechnology, Saarland University, Saarbrücken, Germany and ${ }^{3}$ Department of Genetics and Biotechnology of Ivan Franko National University of L'viv, L'viv, Ukraine

Correspondence: Professor R Müller, Department of Microbial Natural Products, Helmholtz Institute for Pharmaceutical Research Saarland (HIPS), Helmholtz Centre for Infection Research (HZI), Saarland University, Campus C2 3, Saarbrücken 66123, Germany.

E-mail: rom@mx.uni-saarland.de

Received 2 January 2013; revised 8 February 2013; accepted 12 February 2013; published online 3 April 2013 
Table 2 NMR ( $500 \mathrm{MHz}$, methanol- $\left.d_{4}\right)$ data for lorneic acids C (1) and D (2)

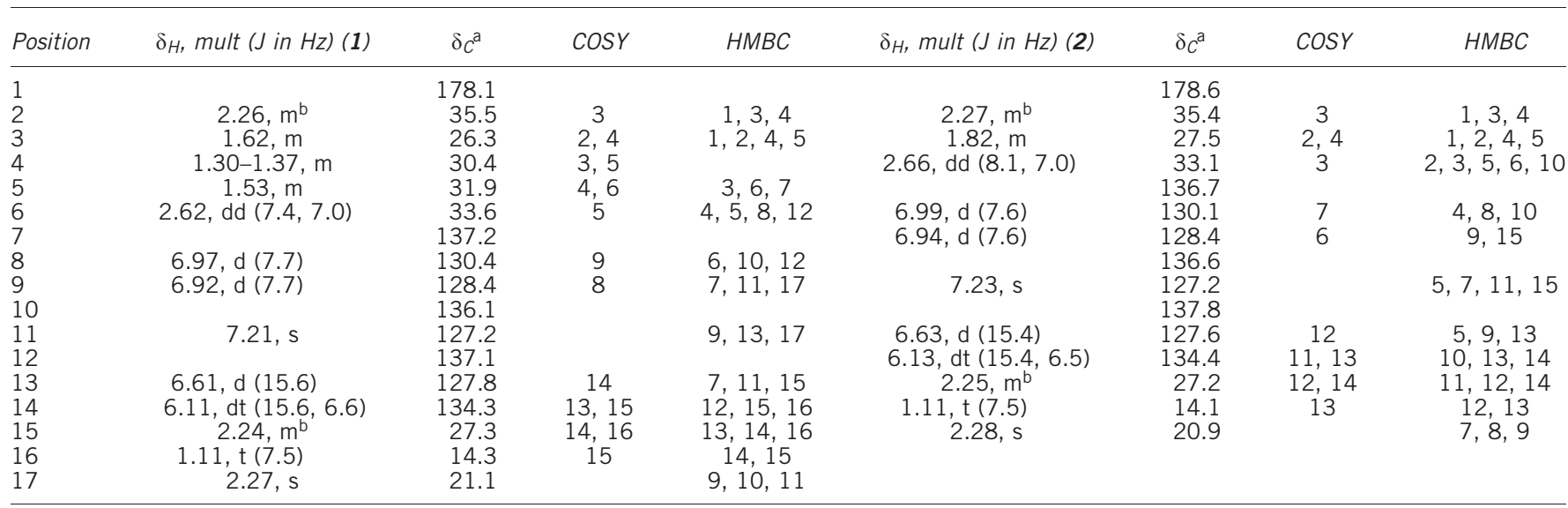

assignments supported by HSQC and HMBC.

boverlapping signals.

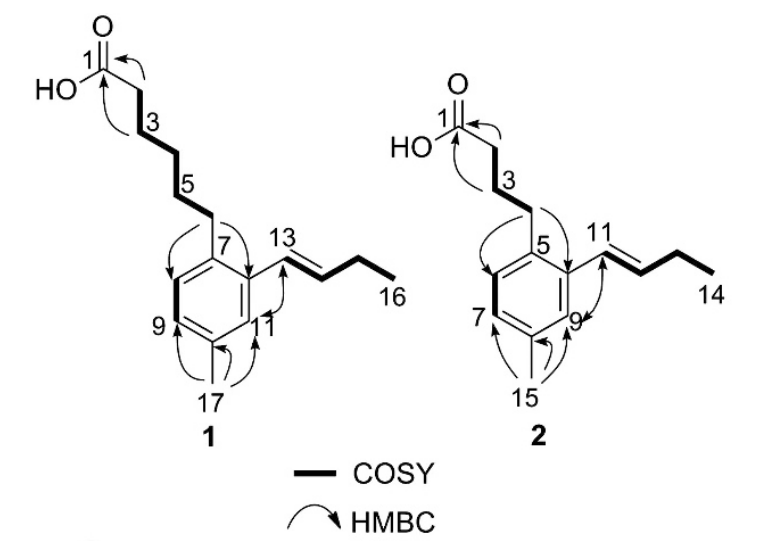<smiles>CCCC(O)/C=C/c1cc(C)ccc1/C=C/CC(N)=O</smiles><smiles>CCCC(=O)CCc1cc(C)ccc1/C=C/CC(N)=O</smiles><smiles>CCCC/C=C/c1cc(C)ccc1/C=C/CC(=O)O</smiles><smiles>CCCCCC(O)c1cc(C)ccc1/C=C/CC(=O)O</smiles>

Figure 1 Key 2D NMR correlations $\left(500\right.$ and $700 \mathrm{MHz}$, methanol- $\left.d_{4}\right)$ for lorneic acids C (1) and D (2) and structures of 3-6.

secondary metabolites, known examples that are limited to lorneamides A (3) and B (4) isolated from an Australian marine-derived Streptomyces sp., ${ }^{3}$ and the recently described phosphodiesterase 5 inhibitors, lorneic acids A (5) and B (6) from a Japanese marine-derived Streptomyces sp. ${ }^{4}$ Lorneic acids C (1) and D (2) exhibited no cytotoxic and antibacterial activity. In summary, the diversity of this rare class of trialkyl-substituted aromatic amides/acids has been further expanded, warranting further investigation of the role of these rare metabolites in nature.

\section{EXPERIMENTAL PROCEDURE}

NMR spectra were obtained on a Bruker Ascend $500 \mathrm{MHz}$ spectrometer equipped with a cryoprobe system (Bruker Biospin GmbH, Rheinstetten, Germany) in the solvents indicated and referenced to residual ${ }^{1} \mathrm{H}$ signals in deuterated solvents. ESI-MS images were acquired using an Agilent 1100 Series separations module equipped with an Agilent 1100 Series LC/MSD mass detector (Agilent, Waldbronn, Germany) in both positive and negative ion modes under the following conditions: Zorbax (Bremen, Germany) $\mathrm{C}_{8}$ column, $150 \times 4.6 \mathrm{~mm}$, eluting with $0.4 \mathrm{ml} \mathrm{min}^{-1} 95 \% \mathrm{H}_{2} \mathrm{O} / \mathrm{MeCN}$ to $5 \%$ $\mathrm{H}_{2} \mathrm{O} / \mathrm{MeCN}$ (with isocratic $0.01 \%$ TFA) over $22 \mathrm{~min}$, and then held for $5 \mathrm{~min}$. HR-MS was carried out using an UltiMate 3000 rapid separation liquid chromatography system (Dionex RSLC, Idstein, Germany) coupled to an UHR-TOF mass spectrometer (Bruker Daltonik maxis, Bremen, Germany) operating in the positive ESI mode.

Sampling was performed in the Nikitsky Botanical Garden of Crimea (Ukraine). The soil was collected from the root zone of Phyllostachys viridiglaucescens. One gram of the collected soil was resuspended in $10 \mathrm{ml}$ of sterile water. Serial dilutions of the soil suspension were prepared in sterile water and inoculated onto the oatmeal agar (oatmeal $-40 \mathrm{gl}^{-1}$, agar $-15 \mathrm{gl}^{-1}, \mathrm{pH} 7.5$ ). The plates were incubated for 20 days at $28^{\circ} \mathrm{C}$. Individual colonies were transferred onto new oatmeal agar plates for further analysis and maintenance. To sequence the 16s rDNA, the chromosomal DNA of Streptomyces sp. Lv 4-15 was isolated according to the protocol described in the literature. ${ }^{5}$ Based on $16 \mathrm{~s}$ rDNA sequence analysis, strain Lv 4-15 was classified as a Streptomyces genus. The strain Streptomyces sp. Lv 4-15 is deposited in the microorganism collection of Ivan Franko Lviv National University.

Strain Lv 4-15 was cultivated in a 250-ml Schott flask containing M1 ( $1 \%$ starch, $0.4 \%$ yeast extract, and $0.2 \%$ peptone) prepared in distilled water $(80 \mathrm{ml})$. The strains were shaken at $145 \mathrm{r} . p . m$. for 8 days at $30^{\circ} \mathrm{C}$, extracted with EtOAc $(50 \mathrm{ml})$, and the organic phase concentrated in vacuo to yield a crude extract of $3.7 \mathrm{mg}$. The crude extracts were redissolved in $\mathrm{MeOH}$, yielding a concentration of $1 \mathrm{mg} \mathrm{ml}^{-1}$, and analyzed by HPLC-DAD-ESI $( \pm)$ MS

Five 5-1 Erlenmeyer flasks containing M1 broth (1.21) were inoculated with starter culture $(20 \mathrm{ml})$ of Streptomyces sp. The flasks were incubated at $30^{\circ} \mathrm{C}$ on a rotary shaker at 150 r.p.m. for 8 days, extracted with EtOAc $(2 \times 500 \mathrm{ml}$ per flask), and the organic phases concentrated in vacuo to yield a combined EtOAc extract $(145.5 \mathrm{mg})$. The EtOAc extract was sequentially triturated with hexane, $\mathrm{CH}_{2} \mathrm{Cl}_{2}$ and $\mathrm{MeOH}$ (40 $\mathrm{ml}$ aliquots), which were concentrated 
in vacuo, to yield $43.3,56.7$ and $13.3 \mathrm{mg}$ partitions, respectively. The $\mathrm{CH}_{2} \mathrm{Cl}_{2}$ soluble material was further fractionated by HPLC (Zorbax, $\mathrm{C}_{8}$ column, $250 \times 9.4 \mathrm{~mm}, 5 \mu \mathrm{m}, 3 \mathrm{ml} \mathrm{min}{ }^{-1}$, gradient from 10 to $100 \% \mathrm{ACN}-\mathrm{H}_{2} \mathrm{O}$ over $30 \mathrm{~min}$, with a $0.01 \%$ FA modifier) to afford lorneic acid C (1) $\left(t_{\mathrm{R}}=25.5 \mathrm{~min}, 0.9 \mathrm{mg}\right)$ and lorneic acid $\mathrm{D}(2)\left(t_{\mathrm{R}}=23.8 \mathrm{~min}, 0.6 \mathrm{mg}\right)$.

\section{ACKNOWLEDGEMENTS}

We thank Angela Kling for performing the biological assays. Research in R.M.'s laboratory was supported by grants from the BMBF and the DFG.
1 Raju, R., Gromyko, O., Fedorenko, V., Luzhetskyy, A. \& Müller, R. Leopolic acid A, isolated from a terrestrial actinomycete, Streptomyces sp. Tetrahedron Lett. 53, 6300-6301 (2012).

2 Raju, R. et al. A new polyketide isolated from a terrestrial actinomycete, Streptomyces sp. Org. Lett. 14, 5860-5863 (2012).

3 Capon, R. J. et al. Lorneamides A and B: two new aromatic amides from a southern Australian marine actinomycete. J. Nat. Prod. 63, 1682-1683 (2000).

4 Iwata, F. et al. Lorneic acids, trialkyl-substituted aromatic acids from a marine-derived actinomycete. J. Nat. Prod. 72, 2046-2048 (2009).

5 Kieser, T., Bibb, M. J., Buttner, M. J., Chater, K. F. \& Hopwood, D. A. Practical Streptomyces Genetics 1-31 (The John Innes Foundation, Norwich, UK, 2000).

Supplementary Information accompanies the paper on The Journal of Antibiotics website (http://www.nature.com/ja) 